\title{
Distribution of Prolyl Oligopeptidase in Human Peripheral Tissues and Body Fluids ${ }^{1}$ )
}

\author{
Filip Goossens, Ingrid De Meester, Greet Vanhoof and Simon Scharpé
}

Laboratorium voor Medische Biochemie, Universiteit Antwerpen (UIA), Wilrijk, Belgium

\begin{abstract}
Summary: Prolyl oligopeptidase (EC 3.4.21.26) activity was measured in human tissue homogenates and body fluids. The enzyme was ubiquitously present, revealing high activity in renal cortex, epithelial cells, fibroblasts, testis, lymphocytes and thrombocytes. The activity in the body fluids was low. Prolyl oligopeptidase activity was significant higher in tumours of prostate, lung and sigmoid, than in the healthy tissues. Sera of individuals suffering from HIV infection, malaria, prostate cancer or benign prostate hypertrophy contained lowered activity. Interestingly, the low serum activity during prostate carcinoma increased upon medical treatment with anti-androgens. This suggests hormonal control of the gene transcript. A positive correlation with angiotensin converting enzyme activity in hypertensive patients was demonstrated and this further supports the possible involvement of prolyl oligopeptidase in the renin-angiotensin system and in the pathogenesis of hypertension.
\end{abstract}

\section{Introduction}

Proline occupies a special position among the 20 different amino acids. Being the only cyclic amino acid, its rigid structure imposes several constraints on a peptide bond. The presence of an imino instead of an amino group prevents the amino acid from forming hydrogen bonds. Furthermore, the cyclic structure decreases the energy difference between the cis and the trans conformation, so that a larger percentage of X-Pro bonds supports the cis conformation rather than the all-trans conformation. On account of these factors, peptide bonds involving proline are seldom cleaved by classical serine endopeptidases, since they hardly fit in the active site (1). Within any protein, proline residues therefore generally represent sites that are resistant to proteolytic cleavage (2).

Prolyl oligopeptidase (post proline cleaving enzyme, prolyl endopeptidase) ${ }^{2}$ ) is the only proline specific endopeptidase presently known in mammals (3). The enzyme was discovered by Walter and colleagues (4) as an oxytocin degrading enzyme. It cleaves peptides at the carboxyl side of proline if this amino acid is preceded by at least two residues (5). This cytosolic serine endopeptidase has been purified from bacterial sources (6) and human tissues (7). Since the enzyme can only hydrolyse small peptides (8) it is thought to be involved in

\footnotetext{
1) Funds: Nationaal Fonds voor het Wetenschappelijk Onderzoek en Interuniversitaire Attractiepolen. Dr. I. De Meester and Dr. G. Vanhoof are senior research assistants of the Nationaal Fonds voor het Wetenschappelijk Onderzoek.

2) Enzymes:

Angiotensin converting enzyme (EC 3.4.15.1)

Prolyl oligopeptidase (EC 3.4.21.26)
}

the metabolism of neuropeptides. Indeed, peptides like oxytocin, bradykinin, substance $P$ and angiotensin (7) are substrates of the enzyme. Although its substrate specificity is well documented, the physiological role of prolyl oligopeptidase remains unclear. We demonstrated that the serum enzyme activity correlates with the different stages of depression (9), and Yoshimoto provided evidence that inhibitors of the enzyme can prevent scopolamine-induced amnesia (10).

The sequence of the human enzyme was established (11) and no homology was found with peptidases of known structure. Prolyl oligopeptidase is a member of the family of the oligopeptidases, a new class of enzymes with specificity limited to small peptides $(7,12)$.

It was the aim of this work to determine the specific activity of prolyl oligopeptidase in several human tissues. The enzyme was present in several tumour tissues, and serum prolyl oligopeptidase activity was altered in a number of pathological conditions. Increasing evidence that prolyl oligopeptidase participates in the renin-angiotensin system also justifies the investigation of its activity in hypertensive individuals (13).

\section{Materials and Methods}

\section{Materials}

The synthetic substrates used for the determination of prolyl oligopeptidase and angiotensin converting enzyme were obtained from Bachem (Bachem, Bübendorf, Switzerland). The inhibitor Z-thioproline-thioprolinal was kindly provided by Dr. Kato, Yakult Co. (Yakult Honsha, Furudai, Japan). All other reagents were of analytical grade and were purchased from Merck (Merck, Darnistadt. Gcrmany). The fluorimeter was from Shimadzu (Shimadzu Europe, Köln, Germany). The centrifuge was from Beckman (Beckman In- 
struments, München, Gcrmany). The reagent for the protcin determination was obtained from Picrce (Pierce Chemical Co., Rockford. IL, USA).

\section{Body fluids}

Blood, urine and spcrm were obtained from apparently healthy donors. The prostatic fluids were obtained from vasectomized persons. Pathological sera were obtained from the University Hospital, Antwerp.

Blood samples ivere centrifuged at $900 \mathrm{~g}$ for $10 \mathrm{~min}$ and the serum was stored at $-20^{\circ} \mathrm{C}$.

\section{Tissues}

The different tissues were obtained by open surgery. Except when especially stated, only those parts not involved in the disease status were used. Prostatectomy was performed in patients with prostatic carcinoma and benign prostatic hypertrophy. Normal prostate tissue was acquired from patients with bladder cancer. All tissues were washed with cold saline and stored as soon as possible in liquid nitrogen, and kept frozen at $-80^{\circ} \mathrm{C}$. Tissue homogenates were prepared by grinding the tissues in a Potter-Elvejhem homogenizer either with one drop of Nonidet P40 per $200 \mathrm{mg}$ of tissue, or by the method of Lazo \& Quinn (14), using a $30 \mathrm{mmol} / \mathrm{l}$ solution of octyl- $\beta-D$-glucopyranoside. After centrifugation at $50000 \mathrm{~g}$ for 30 min at $4{ }^{\circ} \mathrm{C}$ the supernatant was stored at $-80^{\circ} \mathrm{C}$ until measurement of the enzymatic activity and protein content. Vero-cells (monkey kidney tumour), melanoma cells, fibroblasts, endothelial cells, epithelial cells and breast tumour cells were obtained from monolayer cultures. They were washed analogously but the solubilization was performed by adding $10 \mathrm{~m} / /$ Triton $X-100$ and centrifugation at $100000 \mathrm{~g}$ at $4^{\circ} \mathrm{C}$ for $60 \mathrm{~min}$.

\section{Differential centrifugation of seminal plasma}

Seminal plasma was centrifuged at $900 \mathrm{~g}$ for $10 \mathrm{~min}$ at $4{ }^{\circ} \mathrm{C}$ in a MSE HI-spin 21 centrifuge, resulting in a supernatant and a pellet containing the spermatozoa. The supernatant was centrifuged at $105000 \mathrm{~g}$ for $120 \mathrm{~min}$ at $4^{\circ} \mathrm{C}$ in a Beckman ultracentrifuge model L350 to precipitate the prostasomes. The supernatant contains the seminal fluid. The spermatozoan and prostasomal pellets were re-

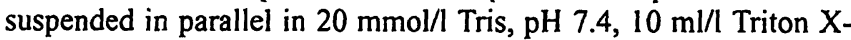
100 , and centrifuged at $40000 \mathrm{~g}$ for $20 \mathrm{~min}$ at $4^{\circ} \mathrm{C}$.

\section{Angiotensin converting enzyme determination}

Angiotensin converting enzyme was determined using 3-(2-furylacryloyl)-phenyl-glycyl-glycine as substrate and measuring the absorbance at $340 \mathrm{~nm}$ in a Cobas-Bio centrifugal spectrophotometric analyser (Roche, Basel, Switzerland) according to Neels et al. (15).

\section{Protein determination}

Protein concentrations were determined by the bi-cinchoninic acid detection reagent from Pierce. The protocol was followed according to the manufacturer. Bovine serum albumin was used as a standard.

\section{Enzyme assay}

After thawing, the samples were centrifuged in an Eppendorf centrifuge at $10000 \mathrm{~min}^{-1}$ for $10 \mathrm{~min}$ at $4^{\circ} \mathrm{C}$. The supernatant was used for the measurements. Prolyl oligopeptidase activity was determined using the fluorogenic substrate $N$-benzyloxycarbonylglycyl-prolyl-7-amino-4-methylcoumarin (Z-Gly-Pro-NHMec). 7Amino-4-methylcoumarin was used as the standard. The substrate was dissolved in dimethylsulphoxide at a concentration of 5.6 $\mathrm{mmol} / \mathrm{l}$.

A $10 \mu \mathrm{l}$ sample was incubated in $100 \mu \mathrm{l}$ assay buffer $(100 \mathrm{mmol} / \mathrm{l}$ $\mathrm{K}_{2} \mathrm{HPO}_{4}, \mathrm{KH}_{2} \mathrm{PO}_{4}$, pH 7.5 containing $1 \mathrm{mmol} / 1$ dithiothreitol, $1 \mathrm{mmol} / 1 \mathrm{NaN}_{3}$ and $1 \mathrm{mmol} / \mathrm{l} \mathrm{EDTA}$ ) at $37^{\circ} \mathrm{C}$. After equilibration for $3 \mathrm{~min}, 5 \mu \mathrm{l}$ substrate were added. The assay was stopped after $20 \mathrm{~min}$ by the addition of $500 \mu \mathrm{l}$ acetic acid $(1.5 \mathrm{~mol} / \mathrm{l})$. The fluo- rescence was measured at $\lambda_{\mathrm{cx}} 370$ and $\lambda_{\mathrm{cm}} 440 \mathrm{~nm}$, slidwidth 1.5 $\mathrm{nm}$. All tissue samples were determined according to this protocol. The body fluids were determined analogously, but they were incubated for $120 \mathrm{~min}$ at $37^{\circ} \mathrm{C}$ prior to addition of the stop solution (16).

\section{Inhibition}

$\cdot 1$

$N$-Benzyloxycarbonyl-thioprolyl-thioprolinal was dissolved in methanol (stock $10 \mathrm{mmol} / \mathrm{l}$ ). After the addition of inhibitor to a final concentration of $100 \mathrm{nmol} / \mathrm{l}$, the mixture with enzyme in assay buffer contained $3 \mathrm{ml} / \mathrm{l}$ methanol. The enzyme was preincubated at $37^{\circ} \mathrm{C}$ for $20 \mathrm{~min}$ after which the residual activity was determined by the addition of $5 \mu \mathrm{l}$ substrate. A control experiment was performed to determine the influence of the solvent (methanol).

\section{Results}

\section{Tissue distribution}

Prolyl oligopeptidase was found to be distributed ubiquitously. The low levels present in the human body fluids correspond to previous reports $(16-18)$. Proliferating tissues revealed enhanced activity. Figure 1 shows the enhanced prolyl oligopeptidase activity for malignancies of lung (13.4 vs. $5.1 \mathrm{U} / \mathrm{g}$ ), prostate (hypertrophy; 23.3 vs. $4.1 \mathrm{U} / \mathrm{g}$ ), prostate (cancer; 6.4 vs. $4.1 \mathrm{U} / \mathrm{g}$ ) and sigmoid (carcinoma; 34.1 vs. $4.0 \mathrm{U} / \mathrm{g}$ ). The addition of $100 \mu \mathrm{l} \mathrm{Z}$-thiopro-thioprolinal abolished all activity, confirming that prolyl oligopeptidase was responsible for the activity measured. Vero-cells, monkey kidney tumour cells, contain the highest activity $(36.7 \mathrm{U} / \mathrm{g})$. These latter cells also display higher activity than that found in human renal tissue, but this may be a reflection of the difference between species, which could obscure the interpretation of this result. The enzyme activity in the renal cortex is 45 times higher than in the medulla (fig. 1). This renal distribution parallels that of angiotensin converting enzyme (19) and dipeptidyl peptidase IV (20). The results confirm that both lymphocytes and thrombocytes are suitable sources for studies on human prolyl oligopeptidase, including characterization and purification of the protein (7) and exploration the gene (12).

\section{Prolyl oligopeptidase in pathological sera}

Investigation of pathological sera demonstrates a decreased enzymatic activity in sera of patients suffering from HIV infection, malaria, benign prostate hypertrophy and prostate cancer (fig. 2). Interestingly, patients affected by prostate cancer reveal enhanced prolyl oligopeptidase activity if treated with anti-androgens.

It was proven that the serum prolyl oligopeptidase level of healthy persons varies within narrow margins (16) and exhibits seasonal fluctuations (21). The origin of serum prolyl oligopeptidase is still unknown. It can be calculated that the total activity of prolyl oligopeptidase circulating in serum equals $2.3 \mathrm{U}$. Prolyl oligopeptidase 
is not secreted from cells so it only can enter the serum compartment due to cell leakage or cell lysis. Five litres of human blood contain approximately $1.5 \times 10^{12}$ platelets, accounting for $2580 \mathrm{mg}$ platelet protein (22). Since the specific activity of the platelets is $9 \mathrm{mU} / \mathrm{mg}$ this means that the platelets contain approximately $24 \mathrm{U}$ prolyl oligopeptidase. This is 10 times the amount present in serum. Platelets, together with the endothelial cells, might be the source of the serum enzyme. Because of the low activity measured in the liver, the contribution of this tissue to the circulating prolyl oligopeptidase can be neglected.

The prolyl oligopeptidase activity was measured in 19 untreated renal hypertensive patients. The results show a significant positive correlation between serum angio- tensin converting enzyme and prolyl oligopeptidase $(n=19, r=0.727, p<0.001$ ) (fig. 3 ). In view of the suggested involvement of prolyl oligopeptidase in the renin-angiotensin cascade and the in vivo metabolism by this enzyme of peptides participating in the blood pressure, this correlation supports the possible importance of this enzyme in the aetiology of hypertension (13).

\section{Discussion}

A major finding of this study is the elevated level of prolyl oligopeptidase in tumour tissues (fig. 1). This may indicate participation of the enzyme in the cell cycle and its up-regulation during stress conditions. Our results correspond to reports of other groups $(23-25)$, who de-

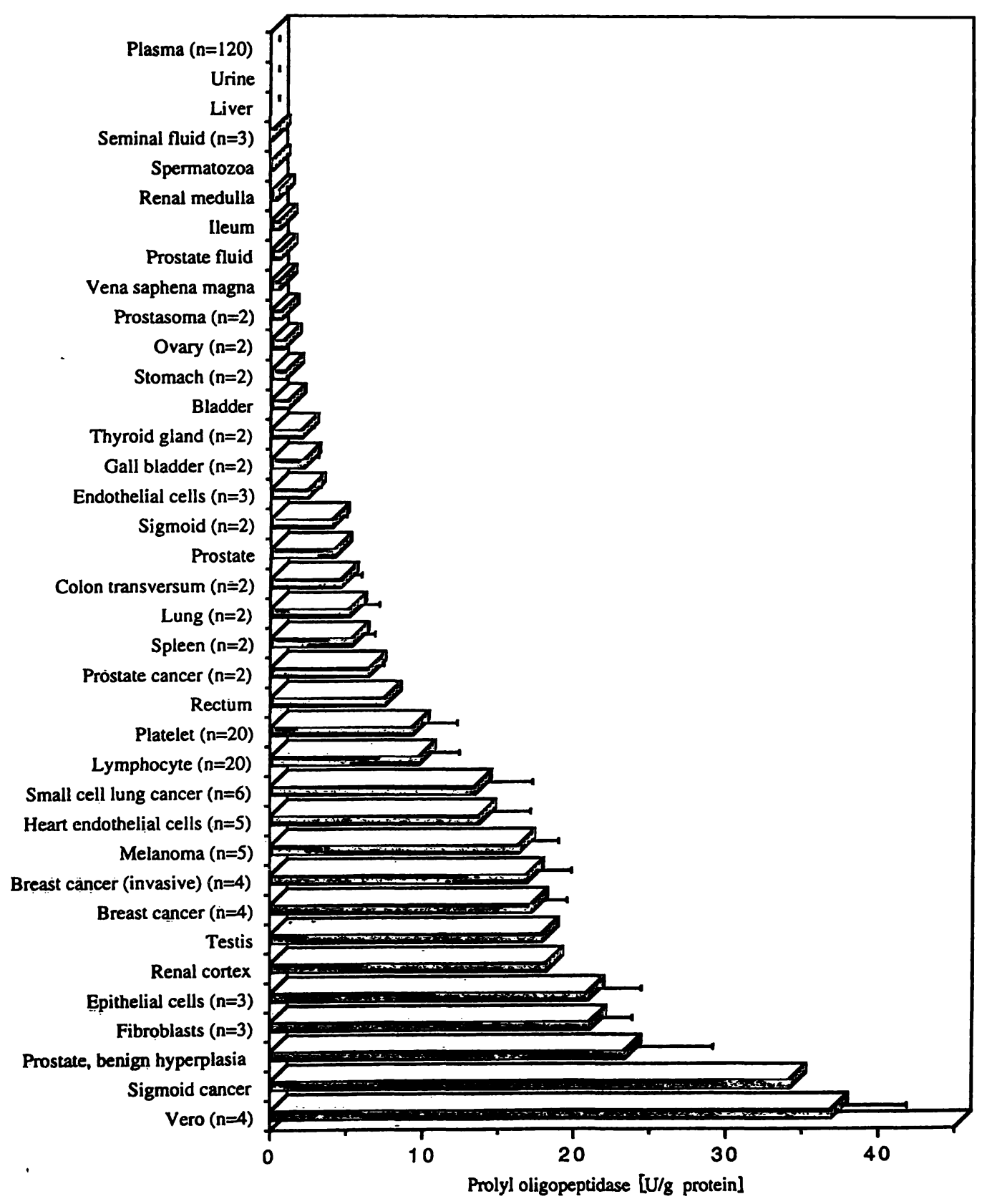

Fig. 1 Screening of prolyl oligopeptidase in tissue extracts, body fluids and several cell cultures.

All biological samples are of human origin, except the heart endothelial cells which are of porcine origin, and the vero-cells which are cultured monkey kidney tumour cells. The $X$-axis displays the specific activity in U/g protein. Each bar gives the mean value and the range of enzymatic activity. 
monstrated enhanced activity of this enzyme in regenerating tissues after injury. It is not known whether this enhanced activity in malignant tissues results from an interaction at the protein level, or has a genetic background. Specific and biocompatible inhibitors for prolyl oligopeptidase should prove valuable in determining whether this enzyme is related to the process of malignancy.

The lack of correlation between the enhanced prolyl oligopeptidase activity in prostate pathologies (fig. 1) and the corresponding serum activity (fig. 2) indicates that alterations of the tissue enzyme are not reflected in the body fluids. It therefore appears impracticable to use serum prolyl oligopeptidase as a tumour marker.

Treatment of patients suffering from prostate carcinoma with anti-androgens results in the restoration of the se- rum prolyl oligopeptidase activity, suggesting that a hormonal component, possibly a steroid, is regulating the enzyme activity. This is in accordance with the reports of Yasuda et al. (26) who found increased prolyl oligopeptidase activity after cortisol administration to human placenta tissue culture. Ohta reported elevated prolyl oligopeptidase activity following addition of progesterone or oestradiol to ovariectomized mice. Intact mice showed a variation of prolyl oligopeptidase activity during the menstrual cycle, exhibiting a maximum at estrus and a minimum at diestrus (27). Interestingly, Fransen et al. isolated a cytosolic $M_{\mathrm{r}} 80000$ protein which crossreacted with antibodies against hsp90 $\left(M_{\mathrm{r}} 90000\right.$ heat shock protein), which is an intracellular steroid receptor, and identified it as prolyl oligopeptidase (28). The serum prolyl oligopeptidase activity correlates with serum angiotensin converting enzyme in hypertensive individuals

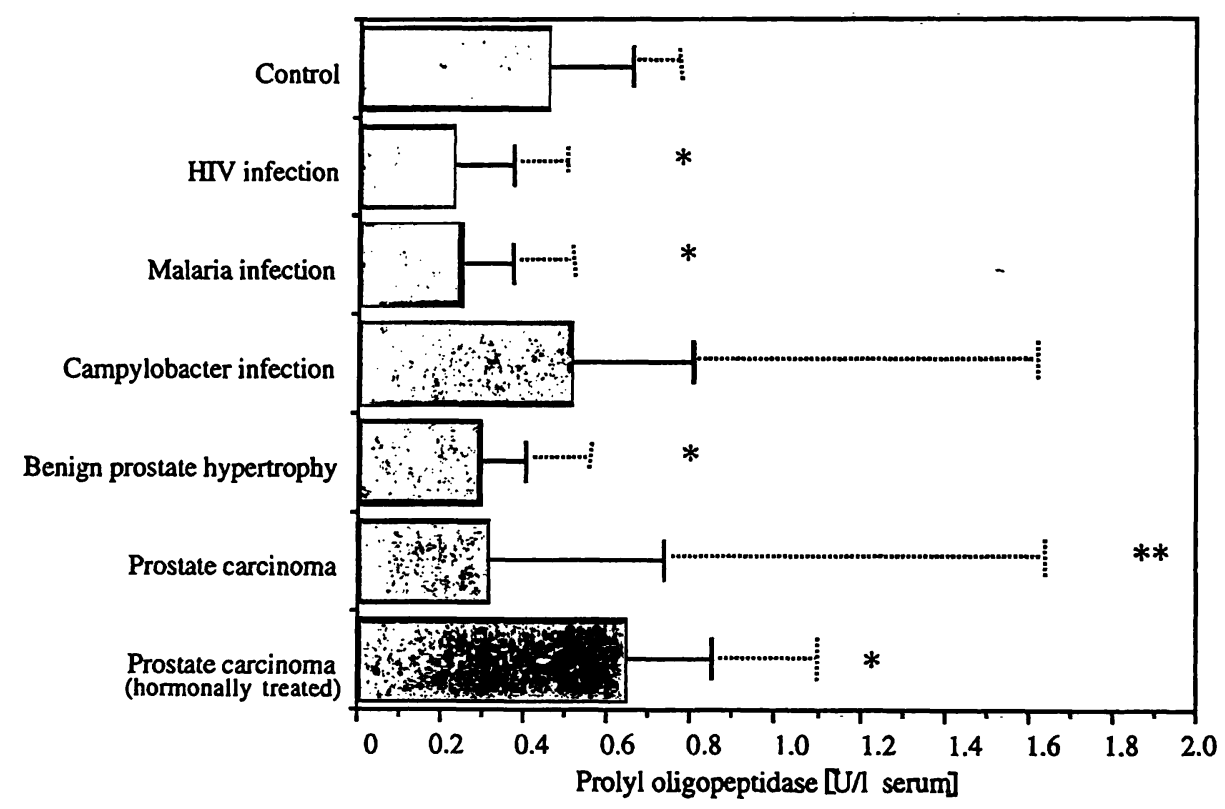

Fig. 2 Prolyl oligopeptidase activity in pathological sera. Each bar represents the mean and the range of the enzymatic activity determined. In boldface are indicated the 10th and 90 th percen- tile. The results were analysed with the Student $\mathrm{t}$-test. The asterix $\left({ }^{*}\right)$ indicates a $p<0.01$ and the double asterix $\left({ }^{* *}\right)$ means the statistical significance is $0.01<\mathrm{p}<0.05$.

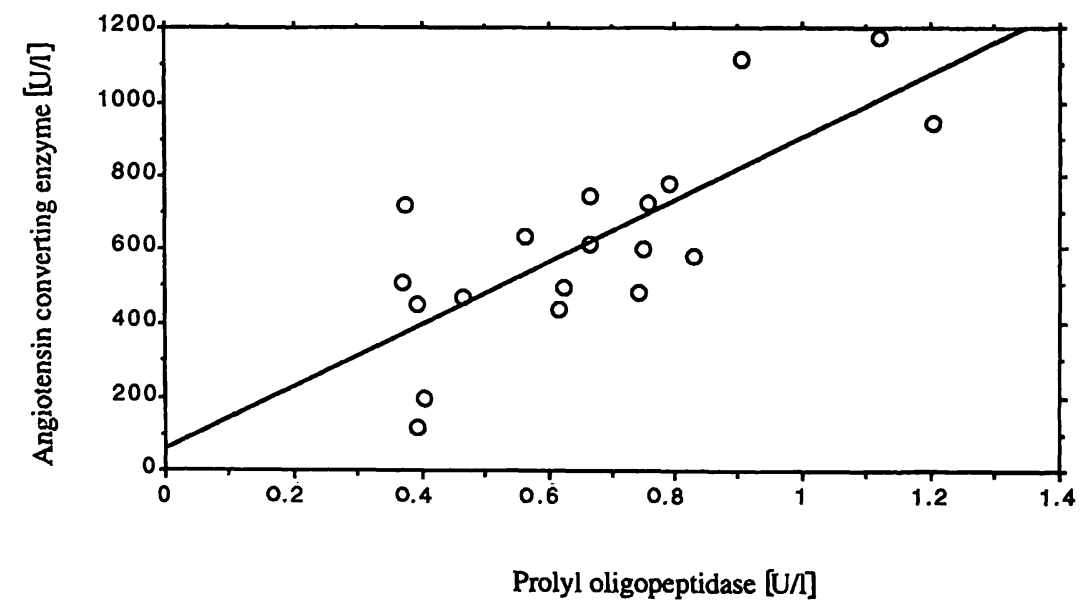

Fig. 3 Correlation of the prolyl oligopeptidase and angiotensin converting enzyme activity in sera of patients affected by renovascular hypertension.

The $\mathrm{x}$-axis displays the prolyl oligopeptidase activity in $U / 1$ and the $y$-axis shows the serum angiotensin converting enzyme activity in U/l. The correlation coefficient is 0.727 and is significant $(p<0.001)$. 
(fig. 3) and the renal distribution equals that of angiotensin converting enzyme. The lower activity in the medulla might be interpreted with respect to the pharmacology of vasopressin, a substrate of prolyl oligopeptidase. Vasopressin exerts its potent antidiuretic effect in the medulla, and inactivation by prolyl oligopeptidase could result in excessive diuresis leading to dehydratation. In view of the similarity in substrates, e.g. angiotensin peptides and bradykinin, and renal distribution, the correlation demonstrated in this study points to a participation of prolyl oligopeptidase in the renin-angiotensin system and blood pressure management. The hypertensive effect of angiotensin converting enzyme, through its generation of angiotensin II and the metabolism of bradykinin, might be amplified by the concomitant rise in prolyl oligopeptidase activity. Like angiotensin converting enzyme, prolyl oligopeptidase rapidly inactivates bradykinin. Prolyl oligopeptidase converts both angiotensin I and II to angiotensin (1-7) as already demonstrated in vitro (29) and in in vivo models $(30,31)$. This peptide has vasodilator activity by the release of vasodilator prostaglandins, prostaglandin $\mathrm{E}_{2}$ and 6-oxo-prostaglandin $F_{1 \alpha}(32)$. However, angiotensin $(1-7)$ causes coronary vasoconstrictions and it liberates vasopressin

\section{References}

1. Polgar L. Mechanisms of protease action. Boca Raton, Florida, USA: CRC Press Inc, 1990.

2. Keil B. Specificity of proteolysis. Berlin: Springer-Verlag, 1993:1-46.

3. Vanhoof G, Goossens F, De Meester I, Scharpé S. Proline motifs in peptides and their biological processing. FASEB J 1995; 9:736-44.

4. Walter R, Shlank H, Glass JD, Schwartz IL, Kerenyi TD. Leucylglycinamide released from oxytocin by human uterine enzyme. Science 1971; 173:827-9.

5. Yoshimoto T, Fischl M, Orlowski R, Walter R. Post-proline cleaving enzyme and post-proline dipeptidyl aminopeptidase. J Biol Chem 1978; 253:3708-16.

6. Yoshimoto T, Walter R, Tsuru D. Proline-specific endopeptidase from Flavobacterium. J Biol Chem 1980; 255:4786-92.

7. Goossens F, De Meester I, Vanhoof G, Hendriks D, Vriend G, Scharpé S. Purification, characterization and analysis of primary and secondary structure of prolyl oligopeptidase from human lymphocytes. Evidence that the enzyme belongs to the $\alpha / \beta$ hydrolase fold family. Eur J Biochem 1995; 233:432-41.

8. Moriyama A, Nakanishi M, Sasaki M. Porcine muscle prolyl endopeptidase and its endogenous substrates. J Biochem 1988; 104:112-7.

9. Maes M, Goossens F, Scharpé S, Meltzer HY, D'Hondt P, Cosyns $P$. Lower serum prolyl endopeptidase enzyme activity in major depression: further evidence that peptidases play a role in the pathophysiology of depression. Biol Psychiatry 1994; 35:545-52.

10. Yoshimoto T, Kado K, Matsubara F, Koriyama N, Kaneto H, Tsuru D. Specific inhibitors for prolyl endopeptidase and their anti-amnesic effect. J Pharmacobio-Dyn 1987; 10:730-5.

11. Vanhoof G, Goossens F, Hendriks L, De Meester I, Hendriks $D$, Vriend $G$, et al. Cloning and sequence analysis of the gene encoding human lymphocyte prolyl endopeptidase. Gene 1994; 149:363-6.

12. Barrett AJ, Rawlings ND. Oligopeptidases, and the emergence of the prolyl oligopeptidase family. Biol Chem Hoppe Seyler $1992 ; 373: 353-60$. after central administration (33). With respect to the coronary actions, it is remarkable to note the high prolyl oligopeptidase activity present in porcine heart endothelium. This level is 5 times higher than in human placenta endothelium. Interestingly, spontaneous hypertensive rats contain enhanced amounts of angiotensin $(1-7)$, the product of prolyl oligopeptidase action (34). In addition it was shown that bilateral nephrectomy in dogs decreases the serum angiotensin (1-7) content 10 times, indicating a renal origin of this peptide (35).

In summary, prolyl oligopeptidase activity was found to be distributed in all body tissues and fluids, although the activities in body fluids were lower than in the tissues. The elevated activity of prolyl oligopeptidase in tumour tissues suggests that it has a role in cell cycle control. The upregulation of serum prolyl oligopeptidase activity during treatment with anti-androgens suggests a possible hormonal control of enzyme activity. Our results on the parallel rise of prolyl oligopeptidase and angiotensin converting enzyme in renal hypertension need to be further explored in patients with hypertension of different aetiology.

13. Goldfarb D, Novick A. The renin-angiotensin system: revised concepts and implications for renal function. Urology 1994; 43:572-83.

14. Lazo JT, Quinn DE. Solubilization of pulmonary angiotensinconverting enzyme with $1-O-n$-octyl- $\beta$-glucopyranoside. Anal Biochem 1980; 102:68-71.

15. Neels H, Scharpé S, van Sande M, Fonteyne G. Sensitive colorimetric assay for angiotensin converting enzyme in serum. Clin Chem 1984; 30:163-4.

16. Goossens F, De Meester I, Vanhoof G, Scharpé S. A sensitive method for the assay of serum prolyl endopeptidase. Eur J Clin Chem Clin Biochem 1992; 30:235-8.

17. Yoshimoto T, Ogita K, Walter R, Koida M, Tsuru D. Postproline cleaving enzyme: synthesis of a new fluorogenic substrate and distribution of the endopeptidase in rat tissues and body fluids of man. Biochim Biophys Acta 1979; 569:184-92.

18. Kato T, Okada M, Nagatsu T. Distribution of post-proline cleaving enzyme in human brain and the peripheral tissues. Mol Cell Biochem 1980; 32:117-21.

19. van Sande M, Scharpé S, Neels H, Van Camp K. Distribution of angiotensin converting enzyme in human tissues. Clin Chim Acta $1985 ; 147: 255-60$.

20. Vanhoof G, De Meester I, van Sande M, Scharpé S. Distribution of proline-specific aminopeptidases in serum, tissues and body fluids. Eur J Clin Chem Clin Biochem 1992; 30:333-8.

21. Maes M, Scharpé S, De Meester I, Goossens F, Wauters A, Neels $\mathrm{H}$, et al. Components of biological variation in prolyl endopeptidase and dipeptidyl peptidase IV activity in plasma of healthy subjects. Clin Chem 1994; 40:562-6.

22. Packham MA, Rand ML, Kinlough-Rathbonet RL. Similarities and differences between rabbit and human platelet characteristics and functions. Comp Biochem Physiol 1992; 1:35-54.

23. Iida $T$, Nozaki $Y$, Fukuyama K, Epstein WL. An improved noninfectious murine skin model of organized granulomatous inflammation. Experientia 1991; 47:273-7.

24. Salcrs P. Enhancement by streptozotocin-induced diabetes of pancrcatic prolyl oligopeptidase activity in neonatal rats. Regul Pept 1994; 50:101-11. 
25. Yamakawa N, Shimeno H, Soeda $\bar{N}$, Nagamatsu A. Regulation of prolyl oligopeptidase activity in regenerating rat liver. Biochim Biophys Acta 1994; 1199:279-84.

26. Yasuda Y, Mizutani S, Kurauchi O, Kasugai M, Narita O, Tomoda $Y$. Induction by cortisol of aminopeptidases production from the human placenta in tissue culture. Horm Metab Res 1992; 24:110-4.

27. Ohta N, Takahashi T, Mori T, Park M, Kawashima S, Takahashi K, Kobayashi H. Hormonal modulation of prolyl endopeptidase and dipeptidyl peptidase IV activities in the mouse uterus and ovary. Acta Endocrinol 1992; 127:262-6.

28. Fransen $M$, De Brees $C$, de Béthune $B$, Van Veldhoven $P$, Mannaerts $\mathrm{G}$. The cytosolic protein that binds the C-terminal part of rat acyl-CoA oxidase is not a peroxisomal import receptor but a prolyl-endopeptidase. Biochim Biophys Acta 1994; 1201:157-64.

29. Welches WR, Brosnihan KB, Ferrario CM. A comparison of the properties and enzymatic activities of three angiotensin processing enzymes: angiotensin converting enzyme, prolyl endopeptidase and neutral endopeptidase 24.11. Life Sci 1993; 52:1461-80.

30. Welches WR, Santos RAS, Chappell MC, Brosnihan KB, Greene LJ, Ferrario CM. Evidence that prolyl endopeptidase participates in the processing of brain angiotensin. J Hypertension 1991; 9:631-8.

31. Chappell MC, Tallant EA, Brosnihan KB, Ferrario CM. Processing of angiotensin peptides by NG108-15 neuroblastoma x Glioma Hybrid Cell Line. Peptides 1990; 11:375-80.

32. Ferrario C, Brosnihan B, Diz D, Jaiswal N, Khosla M, Milsted A, Tallant E. Angiotensin (1-7): a new hormone of the angiotensin system. Hypertension 1991; III' Suppl 18:III126-33.

33. Schiavone M, Santos R, Brosnihan B, Khosla M. Release of vasopressin from the rat hypothalamo-neurohypophysial system by angiotensin(1-7) heptapeptide. Proc Natl Acad Sci USA 1988; 85:4095-8.

34. Kohara K, Brosnihan K, Ferrario C. Angiotensin $(1-7)$ in the spontaneously hypertensive rat. Peptides 1993; 14:883-91.

35. Kohara K, Brosnihan K, Chappell M, Khosla M, Ferrario C. Angiotensin $(1-7)$ a member of circulating angiotensin peptides. Hypertension 1991; 17:131-8.

Received May 31/September 20, 1995

Corresponding author: Dr. Filip Goossens, Laboratorium voor

Medische Biochemie, Universiteit Antwerpen (UIA),

Universiteitsplein 1, S-6, B-2610 Wilrijk, Belgium 